\title{
The role of tourism in a changing climate for conservation and development A problem-oriented study in the Kailash Sacred Landscape, Nepal
}

\author{
Journal Article \\ Author(s): \\ Adler, Carolina Ester; McEvoy, Darryn; Chhetri, Prem; Kruk, Esther \\ Publication date: \\ 2013-06 \\ Permanent link: \\ https://doi.org/10.3929/ethz-b-000058883 \\ Rights / license: \\ In Copyright - Non-Commercial Use Permitted \\ Originally published in: \\ Policy Sciences 46(2), https://doi.org/10.1007/s11077-012-9168-4
}




\title{
The role of tourism in a changing climate for conservation and development. A problem-oriented study in the Kailash Sacred Landscape, Nepal
}

\author{
Carolina E. Adler • Darryn McEvoy $\cdot$ Prem Chhetri • Ester Kruk
}

Published online: 16 October 2012

(C) Springer Science+Business Media New York 2012

\begin{abstract}
An interdisciplinary study was conducted in the Kailash Sacred Landscape region in north-western Nepal, to explore opportunities for, and barriers to, sustainable tourism as an adaptation strategy, not only for reducing community vulnerability to climate change but also as a poverty-alleviation measure. Whilst the primary focus was on interactions between tourism and climate change, the study revealed a highly complex system, with many social, economic, environmental, and institutional drivers involved. In order to bring some clarity and consistency in the exploration of these complex interactions in context, elements of the policy sciences, primarily problem orientation, were utilised. The exploratory nature of the study, including its objectives and intended use, meant that goal clarification and analyses of trends were based on limited available information. Despite these shortcomings, the study was able to elucidate and clarify on important factors to consider in consultation with relevant participants. Diversification of livelihood options as well as preserving local culture were found to be highly valued-both by the local communities that were consulted as well as for those advocating for a tourism experience that is unique to this region. Harmonising these valued outcomes could be achieved by incorporating and legitimising local traditional knowledge. Insights into further collaboration on the issue of valued outcomes would strengthen and support the knowledge base for an appraisal of possible development pathways.
\end{abstract}

C. E. Adler $(\bowtie)$

Institute for Environmental Decisions, Swiss Federal Institute of Technology (ETH) Zürich, Universitätstrasse 22, 8092 Zürich, Switzerland

e-mail: carolina.adler@env.ethz.ch

D. McEvoy

Climate Change Adaptation Program, RMIT University, GPO Box 2476, Melbourne, VIC 3001, Australia

P. Chhetri

School of Business IT and Logistics, RMIT University, GPO Box 2476, Melbourne, VIC 3001, Australia

E. Kruk

Centre for the Promotion of Imports from developing countries, Ministry of Foreign Affairs, P.O. Box 93144, 2509 AC The Hague, The Netherlands 
Keywords Climate change adaptation - Tourism - Conservation ·

Traditional knowledge $\cdot$ Rapid assessments $\cdot$ Nepal

\section{Introduction}

An interdisciplinary study was conducted in a remote area of the Kailash Sacred Landscape (KSL) region in north-western Nepal, to explore opportunities for, and barriers to, sustainable tourism as an adaptation strategy, not only for reducing community vulnerability to climate change but also as a means to alleviate poverty through diversification of livelihood options. This study was commissioned as a 'rapid assessment' to supplement the information needs of a much larger project designed to support the overall objectives of a conservation initiative for the KSL region. This multi-actor and multi-disciplinary team, commissioned specifically for this study, was provided with specific instructions and guidelines to provide a knowledge base for informing policy and strategy formulation. Therefore, the roles assumed by the investigators in this study were to support broader poverty-alleviation and sustainable regional development goals, by investigating the extent that sustainable tourism could contribute to these goals as a sustainable adaptation strategy. In this context, the need to explore the feasibility of tourism as an adaptation strategy resembles what is now increasingly being termed 'sustainable adaptation', that is, adapting to the impacts of climate change whilst simultaneously addressing sustainable development and poverty-alleviation needs (Eriksen and Brown 2011). This type of response to climate change has been progressively gaining traction over recent years as a means for addressing the impacts of climate change through adaptation in developing countries (Agrawala et al. 2003; Brown 2011; Dubois 2005; Eriksen and O'Brien 2007; Smit et al. 2001). Similarly, this type of response has also seen a concurrent development in studies concerned with disaster risk reduction through adaptation, and vice versa (Thomalla et al. 2006; Prabhakar et al. 2009; Schipper and Pelling 2006; Wisner et al. 2004; Ziervogel et al. 2006; O'Brien et al. 2006). In either case, the overall objective is on the assessment and evaluation of measures that aim at reducing losses of what is intrinsically valued in a given context, including effects of climatic events (Brunner 2001; Brunner and Lynch 2010; Lynch et al. 2008). It is through this approach, conscientious of context, perspective, and boundary object (Lynch et al. 2008), that this study was carried out.

Whilst the primary focus was on specific interactions between tourism and climate change, there was an acknowledgement that other social, economic, environmental, and institutional drivers are also imperative factors in constructing a more comprehensive picture of the broader context, as much of the literature on climate change adaptation now advocates and concurs (Adger et al. 2005; O'Brien et al. 2007; Patt et al. 2009; Schipper and Burton 2008; Smith et al. 2003). A more comprehensive and contextual approach also responds to increasing calls for more cautionary approaches to sustainable adaptation, such as when the perspectives of those to whom the sustainable adaptation measures are meant to serve are not adequately taken into account (Brown 2011; Eriksen et al. 2011). Concerns regarding local context and perspectives were addressed through an exploratory field component to supplement the largely desktop-oriented emphasis of this study. The fieldwork component was viewed as an important task to make sure that reported observations, largely from case studies elsewhere, could be ground-truthed against the specific experiences in KSL Nepal. In terms of a boundary object, that is, a common point of reference for all concerned (Lynch et al. 2008), eliciting views and experiences with recent seasonal fluctuations and associated extreme climatic events proved useful in putting climatic 
change in context, and exploring community perceptions towards them. Exploring experiences with extreme climatic events allow a more tangible appreciation for barriers and opportunities for tourism development faced with climatic change, as well as enabling a more fluid dialogue with those concerned on how climatic change manifests in their specific context (McEvoy et al. 2008; Roman et al. 2010a, b; Roman et al. 2011), and what specific adaptation options are locally envisioned.

In this paper, we specifically focus on our experience with the use of problem orientation as a heuristic tool in guiding this inquiry. This paper begins with a description and overview of this study's aim to clarify opportunities and challenges of tourism as an adaptation strategy, by first presenting the institutional context in which the study was commissioned and the problem investigated ("The Kailash Sacred Landscape Conservation Initiative-an overview of the context and problem" section). This is then followed by an account of the approach adopted to conduct the study ("Tourism and climate change-a rapid assessment study" section), proceeded by an overview of main findings that focuses on elements relevant for the ongoing task of refining the common interest ("Overview of results and trends" section). Finally, in section "Concluding discussion-Tourism in the light of multiple processes of change: are goals compatible?", this paper concludes with a discussion on tourism as a potential strategy for adaptation, including recommendations for the incorporation and legitimisation of local traditional knowledge for the policy process going forward.

\section{The Kailash sacred landscape conservation initiative-an overview of the context and problem}

\section{Institutional setting}

Founded in 1983 with the auspice of the governments of Switzerland and Germany, as well as the United Nations Educational, Scientific, and Cultural Organization (UNESCO), the International Centre for Integrated Mountain Development (ICIMOD) was created as a regional intergovernmental knowledge development and learning centre that has been mandated to serve and work with the eight regional member countries of the Hindu KushHimalayas (HKH) - Afghanistan, Bangladesh, Bhutan, China, India, Myanmar, Nepal, and Pakistan (Schild 2008). Headquartered in Kathmandu, Nepal, ICIMOD's mission is to "...enable and facilitate the equitable and sustainable well-being of the people of the HKH by supporting sustainable mountain development through active regional cooperation..." (ICIMOD 2008). In support of this mission, one of a number of ICIMOD's core activities is to support the efforts of countries in the HKH region in their implementation of the Convention on Biological Diversity (CBD), ${ }^{1}$ of which all countries in the HKH are signatories. Given the vast number of regulatory and non-regulatory frameworks that the CBD aimed at streamlining and institutionalise, the HKH region became involved in a process of developing national biodiversity strategies and biodiversity action plans, which included the drafting of new policies and legal instruments as well as the establishment of institutional means to respond to the requirements of the CBD (Desai et al. 2011). In keeping

\footnotetext{
1 The CBD is a formal and legally binding multi-lateral pledge to conserve places recognised for their biological diversity, to sustainably use their natural resources, and to share equitably the benefits arising from the use of these resources. The Convention was opened for signature at the United Nations Conference on Environment and Development in Rio de Janeiro, 1992, and came into force in 1993 (Secretariat of the Convention on Biological Diversity 2000).
} 
with the CBD's programmes for implementation, ICIMOD became involved in assisting the $\mathrm{HKH}$ region in their implementation of CBD requirements by helping to identify seven globally significant and transboundary conservation landscapes in the $\mathrm{HKH}$, namely the Wakhan, Karakoram, Kailash, Everest, Kanchenjunga, Brahmaputra-Salween, and Cherrapunjee-Chittagong conservation landscapes (ICIMOD 2010a). These seven conservation landscapes are at different stages of development. Some are at the initial proposal stage, while others are well under way towards formal development and implementation.

The KSL corresponds to the initiative currently under way for the greater Kailash region, which represents an area approximately 31,175 square kilometres across a southwestern portion of the Tibetan Autonomous Region (TAR) of China, parts of north-western Nepal and northern India (see Fig. 1). It is an area famous for its ancient heritage, pilgrimage routes, and religious significance for Hindu, Buddhist, Bon Po, Jain, Sikh, and other religions, following traditions that go back thousands of years (ICIMOD 2010a). Every year, thousands of people make a pilgrimage to Mount Kailash (6,638 metres above sea level), located within the TAR of KSL, to take part in circumnavigating the 52 kilometres around the base of Mount Kailash (or kora). The 'sacred' meaning for this landscape stems from the Hindu and Buddhist reverence for Mount Kailash as the earthly manifestation of Mount Meru, the spiritual centre of the universe, and home to the Hindu Lord Shiva (Brockman 2011).

The catchments within KSL are source to four of Asia's great rivers, including the Indus, Brahmaputra, Karnali, and Sutlej, providing direct lifelines and essential transboundary ecosystem goods and services locally, as well as further downstream to large parts of Asia and the Indian sub-continent (ICIMOD 2010a).

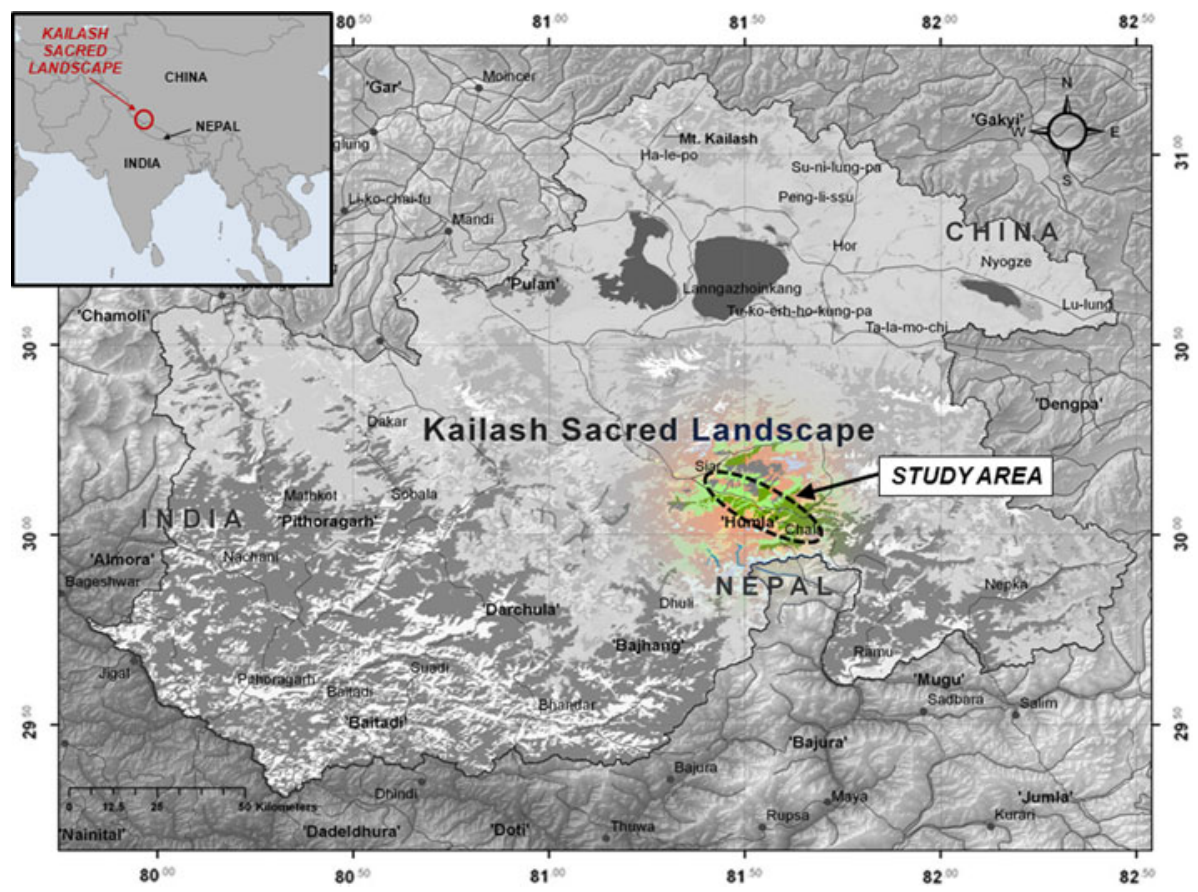

Fig. 1 Study area location (adapted from ICIMOD 2009b) 
Identification of the problem and the role of the KSLCI

Whilst most pilgrims and tourists that visit the Mount Kailash region primarily come from places such as the Indian sub-continent and other parts of Asia, there has been an increase in visitation numbers from other parts of the world as well (ICIMOD 2009a). As a result, tourism and associated infrastructure development has been on the increase and is expected to continue to proliferate, for instance, as new transport hubs such as airports and road construction facilitate access to this remote region (ICIMOD 2009a). In addition to these developments, other processes of global environmental and social change are also said to be unfolding. In seeking to address chronic poverty and diminishing local opportunities for livelihood and well-being, many in the region engage in seasonal labour migration, which has been found to have significant consequences for the demographic composition and principal economic activity in the broader HKH region (Hoermann and Kollmair 2009). Likewise, biophysical pressures such as climatic change are said to be manifesting in the form of extreme events and changing patterns of inter-annual variability or seasonality (see e.g. Bajracharya et al. 2007). This convergence of pressures, coupled with the region's significance and importance for the fulfilment of broader conservation objectives under the CBD, meant that concerns were being raised with respect to the region's capacity to adapt and sustainably transition to a form of development that takes into account local conditions under these processes of change (ICIMOD 2009a). Of particular concern for this region is the lack of context- and place-specific information to be able to appraise these concerns with respect to local perspectives on feasible and desirable means for development.

To address these concerns, the Kailash Sacred Landscape Conservation Initiative (KSLCI) was launched in July 2009 as a long-term interdisciplinary programme led by regional partners within the three countries in the KSL area: China, India, and Nepal, with support of different donors. This initiative seeks to primarily facilitate transboundary and ecosystem management approaches for biodiversity conservation and sustainable development through regional cooperation, and at the time of the study, it was in the process of developing its strategy as part of its preparatory phase (phase one, 2009-2011). The KSLCI is part of a process which is building towards a Regional Cooperation Framework involving China, India, and Nepal, with technical support from ICIMOD and financial support from UNEP, the UK's Department of Foreign and International Development (DFID) and the German agency for international cooperation, the Deutsche Gesellschaft für Internationale Zusammenarbeit (GIZ) $\mathrm{GmbH} .^{2}$

In late 2010 ICIMOD, with the support of GIZ, coordinated the implementation of a 'Strengthening Project', an initiative designed to support intelligence gathering as well as overall objectives of the KSLCI during its first phase. The Strengthening Project was characterised as a rapid assessment that aimed at three major outcomes: 1) that local knowledge on the uses of ecosystem services is documented and assessed in terms of its applicability for adaptation to climate change; 2) that the potential of inclusive eco-tourism as a strategy for adapting to climate change in the Nepalese section of the KSL be analysed; and 3) that the necessary infrastructure and capacity for gathering and continuously monitoring essential environmental and climatic data is in place (ICIMOD 2010b). The tourism component of the Strengthening Project (outcome 2) focused on a study of the potential for tourism as a strategy for livelihood improvement and adaptation to climate change in the KSL. The tourism component consisted of three interrelated sub-components,

${ }^{2}$ At the time of this study in late 2010, GIZ GmbH was known then as the Deutsche Gesellschaft für Technische Zusammenarbeit (GTZ), GmbH. 
these being: 1. Strategic Tourism Planning; 2. Himalaya Heritage Routes; and 3. Tourism and Climate Change. The last of the three, tourism and climate change, was the primary focus of this study with the intention to appraise whether these represent shared goals that could potentially serve a common interest for the KSLCI going forward.

\section{Tourism and climate change - a rapid assessment study}

The study area

Although the project brief identified the study area as being KSL Nepal, which encompasses four districts along the far and midwest regions of Nepal: Baitadi, Darchula, Bajhang, and Humla, the nature of this study meant that an extensive field reconnaissance that encompasses the entire KSL area of Nepal could not be realistically achieved. Therefore, the bulk of the fieldwork component centred on a small area within the district of Humla in north-western Nepal, specifically along the principal trade and pilgrimage route from Simikot to Hilsa that follows the Karnali River towards the border of China. The rationale for selecting this particular area was determined by ICIMOD and its principal partners, largely based on earlier studies that signalled tourism development as a potentially feasible option for one Nepal's most remote and socially disadvantaged mountainous regions (Saville 2001; Majerus 2009; NIDS 2005; Chaudhary et al. 2010).

Located on the far north-western corner of Nepal between $29^{\circ} 35^{\prime}$ and $30^{\circ} 70^{\prime} \mathrm{N}, 81^{\circ} 18^{\prime}$ and $82^{\circ} 10^{\prime} \mathrm{E}$ longitude, Humla is the second largest of 75 districts in the country, covering an area of approximately 6134 square kilometres (Onta and Resurreccion 2011). With a geographic relief ranging from 1,500 to 7,300 metres, Humla is particularly rugged and difficult to access with its northern areas located along the Himalayan mountain region (Parbat) and its lower southern portion in the hills region (Pahar). The district's capital Simikot $(2,950 \mathrm{~m})$ is a 10 -day walk from the nearest motor road in Nepal and 6-7-day walk from the Tibetan border (Saville 2001).

Culturally, Humla (and indeed much of Nepal) can be described as intricately diverse in terms of ethnicity, culture, and religion. There are many inconsistent terms and classifications reported in the literature; however, Jones and Boyd (2011) rely on a Hindu-based Nepali caste system as a means for generally describing this social stratification in terms of Brahmin/Chhetri, Janajati, and Dalit. Largely influential in terms of political and economic power, Brahmin and Chhetri are associated with the highest social order in Nepal, whilst the Janajati are made up of multiple ethnic collectives that despite not being technically part of the Hindu caste system are considered socially better off than lower caste groupings (Jones and Boyd 2011). The Dalits, or 'untouchables', constitute the lowest social order and are often openly discriminated against, particularly in rural areas. In the western Himalayan context, such as in Humla, the social stratification is more coarsely and broadly characterised in terms of two distinct cultural groups: Buddhists 'Lama' of Tibetan origin or Bhotiya (also called Bhotia, Bhot, Bot, Bhutiya, or Bhutia), and the predominantly Hindu mountain dwellers or Khas, who instead refer to themselves by caste, that is, as Brahmin, Chhetri, or Dalit (Onta and Resurreccion 2011; McKay 2002). The Bhotiya are referred to as the indigenous people in western Nepal Himalaya (Onta and Resurreccion 2011; NEFIN 2005).

Humla is said to be particularly significant for understanding the processes of ethnic 'accommodation' or integration, given its long history of ethnic groups living side-by-side as well as non-Hindu communities experiencing Hindu rule for longer than elsewhere in 
Nepal (Levine 1987). Of interest to note, however, are examples of the intra- and intercultural relations and dynamics between these two groups as each employ distinct sets of strategies and resources at their disposal in pursuit of their own goals and valued outcomes. For instance, certain Bhotiya villages in Humla, particularly in the Limi Valley, practice polyandry ${ }^{3}$ as a practical means to pool resources and reduce their demands as a population on the extremely limited natural resources and options for subsistence and livelihood in these high-altitude, rugged, and remote valleys (McKay 2002; Gurung 1993; Levine 1987). However, despite its existence over hundreds if not thousands of years, its predominance is said to be in decline given outside pressures and drivers such as globalisation, seasonal work migration, and modernisation (Chalaune 2010), as well as social disadvantage imposed by a state system centred on ethnicity and caste (Levine 1987). It was not uncommon, for instance, to hear descriptions such as 'undeveloped' or 'backwards' directed at these remote communities, given their polyandry and non-vegetarian customsboth of which are said to be particularly objectionable to Hindus (McKay 2002).

Until recently, tourism as an economic activity has been relatively uncommon and undeveloped in Humla (Saville 2001; Majerus 2009) when compared to other better-known Himalayan destinations in Nepal such as the Khumbu Valley or Annapurna (Gurung and De Coursey 1994; Nyaupane and Thapa 2004; Thapa 2004). Tourism data and statistics specific to Humla were and still remain difficult to obtain and verify; however, indicative numbers of tourists into areas such as Humla can be inferred from the number of trekking permits issued by the Department of Immigration into regions categorised as 'Restricted Areas'4 (MoTCA 2009). Given that trekking and pilgrimage constitute the main tourist activity in Humla, the number of trekking permits issued gives an approximate measure of likely visitors. There has been a steady increase of tourists into Restricted Areas over the last decade, except for a sharp decline during political instability and insurgency in Nepal during the early $2000 \mathrm{~s}$ (Roman and McEvoy 2010). In 2009, a total of 1,177 permits were issued for Humla, compared to just 28 in 1993, with the greatest number of permits issued for the months of April-May as well as September, corresponding to the busiest times for trekkers visiting Nepal. Given the lack of tourism-relevant infrastructure in the region (such as hotels and inns), the most common means for accommodating tourists is through pre-paid and pre-organised camping tours by professional trekking companies, most based in Kathmandu and elsewhere (Chaudhary et al. 2010; Saville 2001).

\section{The research approach}

The study relied upon methods such as a desk-based literature reviews but also relied upon various forms of existing knowledge - both quantitative and qualitative, as well as first-hand

\footnotetext{
${ }^{3}$ Practiced by many ethnic Tibetans, polyandry is described as a marriage system whereby a household of many brothers share a single female wife (Levine 1987; McKay 2002). It results in assets being passed on undivided from one generation to the next (Levine 1987), as well as suppressing fertility rates in the populations (McKay 2002).

${ }^{4}$ Restricted Areas are places that are officially closed to self-serviced trekkers or opened to trekkers only when accompanied by a policeman, liaison, or environmental officer. Reasons for these restrictions vary, but these areas generally correspond to strategic and sensitive border crossings between Nepal and China (Tibet). These are also areas known for trafficking of poached forest goods such as timber wood or herbs and other medicinal plants and are therefore subject to controls (Chaudhary et al. 2010). Permits to these areas are strictly controlled, and numbers of trekkers granted permits are subject to a quota system (MoTCA 2008). For the purposes of this study, the services of an accredited and licensed trekking company were solicited for the arrangement of these permits, as well as to arrange for local guides and porters that accompanied the research team throughout their stay in Humla.
} 
experiences through interviews with relevant stakeholders in the field. The limited time available to conduct such a study (less than a month in the field) meant that a 'rapid assessment process' approach was needed. Rapid assessments are characterised as intensive, multidisciplinary team-based qualitative inquiry using triangulation, iterative data analysis to quickly develop a preliminary understanding of a situation in a given context (Beebe 1995; 2003). Rapid assessments are extensively applied by non-governmental organisations and most development aid agencies, and the knowledge presented in these are largely relied upon for appraisals of programmes or for evaluating the feasibility of up-scaling towards more extensive programmes (Manasfi 2011; The World Bank 2010; Mikkelsen 2005).

The type of tourism development envisaged for the target region reflects a sustainable livelihoods approach through Community-Based Tourism (CBT). The overall study approach was that of a 'bottom-up' and consultative sustainable livelihood approach. A sustainable livelihoods approach entails an understanding of the activities carried out for the subsistence of the community, and associated problems, at the centre of the enquiry (Eriksen and O'Brien 2007; Smit and Wandel 2006). This is also applicable in the tourism development context where tourism can be considered as one of several means for enhancing local livelihoods (Asker et al. 2010; UNWTO 2010). However, one of the main motivations for the study team in conducting a broader inquiry-rather than just solely on the merits of tourism alone-was to try and account for the concerns voiced at tourism as a single policy development option (Beeton 2006; Blackstock 2005; Butler 1999; Kiss 2004), especially given its status as a principal and significant economic activity in Nepal. The primary data were primarily sourced from two stakeholder engagement workshops held in Kathmandu and in Simikot and complemented by individual semi- and unstructured interviews with local community leaders and government representatives, farmers, inn owners and operators, school teachers, and religious leaders from a local Buddhist Lama monastery, over the course of a 10-day trek along the Simikot-Hilsa route.

The CBT concept, also referred to as 'Sustainable Tourism', 'Rural tourism', and 'Ecotourism', is generally small scale involving interactions between visitor and host communities and is particularly suited to rural and regional areas (Asker et al. 2010). Regardless of terminology used, the practice is commonly understood to be one that is managed and owned by the community for the community and is an approach already widely implemented in Nepal (Upreti et al. 2010; Nyaupane and Chhetri 2009). It is a form of tourism practice and business model that sources its goods and services locally, as well as focusing on interpreting and communicating the local culture, its environment, as well as its biodiversity conservation initiatives (Asker et al. 2010; UNWTO 2010). In order to gently steer the focus of semi-structured interviews and workshops towards perceptions of tourism, a modified version of Asker et al. (2010)'s list of enabling conditions and corresponding potential maladaptive pitfalls for tourism development (see Table 1) was used.

The underlying issues highlighted by these conditions (and likely corresponding pitfalls) were used to solicit views and experiences on how these are reflected in Humla, and more specifically, along the primary pilgrimage route from Simikot to Hilsa.

\section{Overview of results and trends}

Summary of field and workshop results

A number of issues were raised by participants as part of the fieldwork phase of the research. Of concern and relevance to the terms of reference for this study were issues 
Table 1 Enabling conditions and barriers to the development of community-based tourism (CBT) initiatives (Roman et al. 2010a; Asker et al. 2010)

Enabling conditions for good practice CBT Barriers to the development of CBT (and potential
'maladaptation' pitfalls)

The community is already well organised and cohesive

When community members are widely involved in decision-making processes, and financial management around the CBT

Land ownership and other 'resource' issues are clear and well defined

'Bottom-up desire', in the community reflected in the facility design, decision-making and management structures.

Decision for CBT is made by the community based on informed choice of impact, options, risk, and outcomes

High participation levels

Driver is not purely income generation but also cultural and natural heritage conservation and intercultural learning

The activity is supported by good marketing mechanisms

A strong plan for expansion and/or to limit visitor numbers in balance with the carrying capacity of the community and environment to avoid adverse effects on both

Strong partnership with local NGOs, relevant government bodies, and other supporters

Approaches are contextually and locally appropriate and not just 'imported' from other contexts

CBT is part of a broader/wider community development strategy

Linked to visitor education on the value of culture and resources present. Clear zoning of visitor and non-visitors areas

There is good existing infrastructure to access the product
The foundations of the community are fragmented and unorganised

Decision-making is purely the domain of powerful individuals (usually males), and the benefits are not equitably distributed

Land and resource disputes are rife and recurrent

'Top-down' centralised decision-making and management structures where CBT is 'placed' on a community. Local perception that the motivations is purely financial

There is no real local decision-making, or it is based on limited information and no consideration of options

Participation wanes during the implementation of the CBT facility

Drivers are solely financial

Little marketing or misplaced marketing

When the provision of tourism services are passive and there is a lack of future planning (to the detriment of the community and the natural landscape)

Established through external funding mechanisms

The CBT venture is seen as a 'one-size pitfall'

CBT is seen as a quick fix 'way up and out' of a poverty cycle

No attempt to inform visitors of the specific nature of local natural and cultural heritage so there is no sense of the uniqueness of 'place'

Infrastructure is inadequate, and there is no potential for investment

pertaining to the interaction between weather, climate, and tourism. However, it was just as important to allow the space and the opportunity for participants to raise other issues of concern, which may or may not be necessarily characterised as climatic factors. Table 2 provides a summary of the main issues of concern raised with respect to weather- and climate-related hazards, as well as other socio-economic factors (listed in no particular order).

The following sub-sections address a select number of issues raised in Table 2, pertaining to concerns that are considered relevant in the context of tourism as well as traditional and indigenous knowledge and values. 
Table 2 Summary of main issues of concern (Roman and McEvoy, 2010)

\begin{tabular}{lll}
\hline $\begin{array}{l}\text { Weather- and climate-related } \\
\text { concerns }\end{array}$ & Other socio-economic issues of concern & \\
\hline - Floods & • Lack of basic infrastructure & $\bullet$ Waste management \\
- Dry conditions (drought) & $\bullet$ Weak socio-economic base & $\bullet$ Illegal hunting and \\
$\begin{array}{l}\text { - Strength and duration of the } \\
\text { monsoon }\end{array}$ & $\bullet$ Lack of energy resources/reliance & poaching \\
- Unseasonal, uncertain, and extreme & $\bullet$ Food insecurity & $\bullet$ High costs of travel, \\
weather conditions & $\bullet$ Loss of cultural identity & goods, and services \\
- Landslides (precipitation) & $\bullet$ Governance issues (multilevel & and tourists \\
- Inadequate long-range weather & policy and politics) & $\bullet$ Unequal distribution of \\
forecasts & $\bullet$ Carrying capacity & opportunities \\
\hline
\end{tabular}

\section{Weather and climate}

Weather- and climate-related concerns were brought up by participants as concrete experiences with extreme events, most prominently being unseasonal monsoon, prolonged dry conditions, and floods. The strength, duration, as well as the onset and end to the 2010 monsoon were a commonly cited problem. Its duration was particularly problematic, as rains persisted well into September when normally this would have ceased much earlier in the season. One impact was reported to centre on halted air transport, given that airplanes could not fly or land into Simikot due to muddy and saturated conditions on the unsealed landing strip; therefore, directly impacting on what would normally be expected to be their busiest time for tourist arrivals.

Prolonged dry conditions were mostly associated with relatively low snowfall levels over the 2009-10 winter. The late winter and spring snowmelt is relied upon for irrigation during the main planting and growing season before the monsoon, but many in Humla reported low yields in production and in some instances even crop failures, an occurrence also experienced elsewhere in Humla since the time of this study (Jones and Boyd 2011; Onta and Resurreccion 2011). Of major concern for this region is the chronic food insecurity issue that has been exacerbated by changing climatic conditions. There are already many existing geophysical constraints for local food production in this region, that is, the availability and space for arable land, soil condition and fertility, altitude, and means for irrigation. This situation has led to a reliance and dependence on subsidised food items supplied under programmes run by the Nepal Food Corporation and supported by the World Food Programme (Hobbs 2009). Whilst alleviation of the short-term food shortage is welcomed, concerns were raised over the long-term effects of this mostly rice-based dependence. Some argued that this dependence is shifting diet patterns that rely on imported food such as rice. This dependence also affects the local agrarian 'know-how' of local endemic food types such as cereals and legumes, as subsistence farming knowledge and techniques are lost to the purchase of food supplies, as also noted by earlier empirical studies on food security in this region (Panter-Brick and Eggerman 1997; Roy et al. 2009). However, some positive aspects of a changing climate were also noted, for instance, the increasing variety of food items such as types of vegetables that can now be grown in relatively warmer conditions compared to earlier years. To capitalise on these opportunities to expand food variety, a few respondents also mentioned the use of (as well as advocacy for) small-scale greenhouses to support food production.

Floods were first brought up during workshops in Kathmandu, with reference to a significant flood event that occurred in Limi Valley (Humla) in the mid-2000 s. Of 
particular concern was the level of exposure and damage to infrastructure such as trails and adjacent land, as well as the potential loss of buildings and a sacred monastery of significant cultural value in the village of Halji (Roman et al. 2010a). Many raised concerns over the glacier at the head of the valley near Halji, which has seen melt water increase in volume in recent times. Since the time of this study, there have been reports of a significant glacial lake outburst flood (GLOF) event that has subsequently struck this village (Singh Khadka 2011), raising concerns over the community's ability to cope with the effects of flooding and the potential loss of revered places of social and spiritual value. For this study, Limi Valley was beyond the logistical capacity afforded and therefore was not part of this reconnaissance. However, its potential as an important tourism draw card has been highlighted by those advocating for tourism development - both by locals in the region and Kathmandu-based stakeholders; however, an adequate assessment against the wishes and valued outcomes sought by this community have not been comprehensively carried out and the pressing circumstances surrounding a rapidly changing environment calls for an urgent prioritisation of such an assessment.

\section{Other issues of socio-economic concern}

Many respondents raised concerns about the integrity and preservation of culture and identity in Humla. Shifts in social values particularly as a result of exposure to and influence of modernisation and globalisation were noted as factors contributing to this trend, as well as education levels amongst those that can afford to obtain schooling (Roman et al. 2010a). Most respondents felt that preserving cultural identity should be a priority going forward and that tourism should support this objective, rather than tourism playing the central role as an end in itself. Poverty, in this context, extends to the loss or insufficient means to support and strengthen cultural values, tradition, and a strong relationship with country and place. Humla is also known for its festivals and shaman rituals, which were said to be of significance to locals but potentially risk being eroded of their genuineness through an increased exposure to and expectations from international tourists. This also raises questions about the issue of local perceptions of tourism and tourists alike. For many in the industry sector, there was discontent expressed towards the government's attitude on tourism, some describing their frustrations at the government's lack of appreciation for the business and commercial realities - in particular, that tourism should not be regarded as a charity. Another issue discussed was that, whilst many tea-house owners along the Simikot-Hilsa route expressed a general acceptance of tourism, there was a resounding perception that the benefits from tourism are unequally distributed and therefore have a perceived low benefit for the broader local community. A common apprehension was directed at tourists that do 'self-sufficient' treks with operators from outside of the region, often sourcing supplies such as food or camping items from Kathmandu and therefore not purchasing locally. This is a problem that is also prominent in other contexts elsewhere in Nepal (e.g. see Nyaupane and Thapa 2004), and therefore empirical evidence exists that supports these claims in such contexts. There was considerable support for arrangements such as 'home stays' and small inns, rather than hotels or larger tea houses, which can cater for the specific needs of smaller groups of tourists also wishing to experience a more genuine cultural exchange with the locals.

Issues relating to governance and institutional capacity were raised by many respondents as significant challenges for current development planning and future tourism development efforts. Some of the main issues of concern centred on the ongoing political instability and volatility within the central government in Kathmandu (Roman et al. 2010a). At the time of the study, Nepal had no Prime Minister since the previous Prime Minister resigned in June 
2010, leaving a political vacuum which effectively stalled institutional decision-making and allocation of funds for many government initiatives and programmes (Jolly 2010). Political instability and conflict in Nepal has had significant impacts on livelihood options in the past-including tourism (Upreti et al. 2010), and many of those interviewed expressed a lack of confidence or trust in the current institutional arrangements to prevent such shocks and impacts from occurring again. A significant point of discussion during workshops centred on the issue of local access to tourism-related revenue such as trekking permit fees. Comments were made that there are rules, regulations, and clauses in Nepali legislation that allow for this transfer and access to revenue streams; however, there is a systemic lack of awareness and/or capacity at local government levels to enact on these provisions and lobby for their access (Roman et al. 2010a). For some respondents in Humla, their relative isolation from central governments meant that they felt marginalised and absent from deliberations on policy decisions of relevance to them. Concerns were raised regarding the noticeable absence of involvement by district government officials and their representatives in local village affairs. These issues represent real risks for well-intentioned and salient initiatives, where programmes or policies are not supported by good functioning institutions that sustainably deliver on the poverty-alleviation initiative (Auer 2007; Bhattachan 2002). Capacity building should also aim at facilitating self-determined solutions that can potentially overcome these institutional barriers, as it was once known to occur in Nepal (Bhattachan 2002).

Issues of illegal hunting and poaching were discussed in the context of logging and timber harvesting in Humla; a practice opted for by locals who seek to supplement their livelihoods by servicing the construction and energy needs in the broader region (Chaudhary et al. 2010). Evidence of logging and timber transportation were observed along the Simikot-Hilsa route, as well as stockpiles of timber products in forested areas. Timber transportation was observed over the Nara La pass towards the Chinese border, where a lack of local government officials and policing in these remote areas means the practice continues unregulated. One respondent also mentioned that timber and non-timber forest products are used by some locals to obtain other goods at the border through bartering. Given that forms of bartering are still practiced in this region, it means that forest products have a certain value and used as a commodity for locals to obtain goods. As noted in the KSL Nepal feasibility report, as well as through responses from numerous respondents in the field, there is significant trade and revenue generated from timber and non-timber forest products in Humla (Chaudhary et al. 2010). Most of these forest-based ecosystem services are said to be managed by the government; however, a significant portion of this activity also falls under community forest management and other arrangements such as leasehold (Chaudhary et al. 2010). Yet, there was no evidence or data available at the time of this field survey to be able to clearly differentiate between the extent of legal and permissible harvesting versus illegal logging and poaching of forest-based products. Studies conducted elsewhere in Nepal suggest that harvesting of forest products in community forests is also highly dependent on numerous socio-economic variables, where land and livestock holdings, caste, education, and economic status play significant roles on how and who gets to appropriate benefits from these goods (Adhikari et al. 2004; Varughese and Ostrom 2001). In many of these cases, it was found that the poorest households face the most restricted access to community forests than 'less poor' or relatively better off households (Adhikari et al. 2004). An additional important consideration for and link between forest goods and related ecosystem services and tourism are with respect to the expected added energy demands that tourism inevitably presents (Nepal 2008; Pokharel 2007). In other parts of Nepal, considerable trends point towards the intensification of energy demands 
from tourism in mountain regions that are mostly serviced from forest timber and other sources such as kerosene (Nepal 2008; Pokharel 2007).

\section{Reflections on the research approach and results}

Using a problem-oriented approach allowed us to focus selectively on those issues and concerns that resonate on the ground. However, one of the most commonly cited problems for rapid assessments is the failure to allow sufficient time to be observant, sensitive, eclectic, and to have multiple iterations on the information gathered and the sense of clarity and understanding that ensues (Beebe 1995). Indeed, this was a concern in the context of this study, particularly during its conclusive phase having felt that we had barely managed to scratch the surface on the tip of a very large iceberg. Many emotions and confronting realities were also felt as part of this study, particularly whilst experiencing hardship under a 'rapid' time frame, as physical acclimatisation and psychological adaptation to basic subsistence were endured at high altitudes along the trek. However, this was precisely the impetus and stimulus that enabled a deeper appreciation for and reflection on the tasks and outputs produced. It was the fear, the anxiety, the surprise, the wonder, the loneliness, the empathy, the laughter, and the joy experienced in such a unique and remote place that crystallised a year for justice and rectitude - not only for those whom we seek to assist, but also for the integrity of research and policy process going forward. Emotions, it seems, have an important role to play in epistemic progress and inevitably demands greater reflection as part of the research process itself (Brun and Kuenzle 2008). As time progressed, more questions have been raised in our minds over the real impacts that can be facilitated through this kind of work in a much longer time scale.

Much of the existing literature - and policy_is based on the assumption that alleviating poverty equates to better capacity in dealing with climatic change. In very general terms, this may seem true; however, Eriksen and O'Brien (2007) provide a more 'shades of grey' take on this proposition by diligently illustrating how experiences and states of vulnerability and poverty are very different. In other words, not all poor people are uniformly vulnerable to climate change in the same way (Eriksen and Brown 2011). From our experience in Humla, issues of poverty and marginalisation also reflect an intricate legacy that is embedded in value systems, cultural prescriptions, and social interactions and dynamics that challenge our pre-conceived interpretation of poverty as purely economically based. But simply knowing about and accounting for diverse forms of poverty and marginalisation are not enough. Desai et al. (2011) assert that the advent of communitybased development initiatives, such as local scale tourism, has stirred debate on the rights of indigenous and marginalised local communities over biological resources in the HKH region. After all, it would be naïve to expect that calls for the integration of such knowledge into developmental processes would not be confronted with powerful political obstacles (Seeland 2000). A 'Kathmandu-based' and highly centralised governance structure as well as a state system that has largely legislated on the basis of ethnicity and caste (Bhattachan 2002) are such very tangible and visible obstacles in Humla.

\section{Concluding discussion-Tourism in the light of multiple processes of change: are goals compatible?}

In this paper, our aim was to report our experiences in using problem orientation to clarify opportunities and challenges of tourism as an adaptation strategy in a vulnerable 
and isolated mountain region of far western Nepal. An overview of the institutional and case study context provided vital insights on the goals and objectives that frame the essence of the problem, which was then verified through our discussions with participants in the field. Overall, our reconnaissance of pertinent issues in context suggest that there are many processes of change manifesting locally that go beyond concerns with climate and tourism alone. Issues pertaining to climate variability and extreme events were of particular concern in exacerbating already chronic and fragile vulnerable conditions, especially with regard to food security and livelihood options through subsistence farming. Claims directed to us as part of stakeholder consultations were generally verifiable through empirical validation; even though in some instances, these empirical findings reflect conditions experienced elsewhere in Nepal. Nevertheless, insights into these experiences provide valuable affirmation that these issues have traction in rural Nepal generally.

Our findings also suggest that goals and aspirations at the local level were generally in agreement and congruent with those promoted by the KSLCI that tourism is broadly valued as a potentially fruitful means to alleviate poverty and promote conservation objectives. However, direct dialogue and engagement with local stakeholders provided valuable perspectives and an added-dimension that clarified on the type of tourism that is both desirable and feasible in this context. One key consideration centres on the importance of governance needed to support the KSLCI in Humla and the legitimisation of local viewpoints in a policy process that is highly centralised. For instance, if sustainable forest practices are to be incorporated as part of a suit of measures and livelihood options in KSL, then there is a critical need to identify and define baselines for future management that considers the close relationship these ecological services have for tourism development potential in the region, as well as the value placed on these commodities by the local indigenous community. In addition, a comprehensive appraisal of legislation, policy, and decision processes and practices needs to be undertaken-both in KSL Nepal and in the wider transboundary region-in order to critically appraise and evaluate the effectiveness of current forest management arrangements against broader sustainability goals under the KSLCI. Such appraisal and evaluation of policies should also be extended to other issues of concern raised, such as addressing food insecurity.

Goals promoted by the KSLCI and those with whom we were able to engage in dialogue are generally congruent and align in seeking to fulfil values such as well-being, skill, wealth, and respect. Yet ultimately, if the goal for tourism is for conservation and the alleviation of poverty, then these need to be validated against a more diverse take on what these would mean for this mix of eclectic clusters of indigenous communities along the Simikot-Hilsa as well as in Limi Valley. Elements of social process, for instance, identification or myths in a Lasswellian tradition (Lasswell 1971), could be used to more adequately align values that point to a refined notion of the common interest. Given this first analysis of issues and concerns in discerning barriers and opportunities for tourism as an poverty-alleviation strategy, questions regarding gender, caste, language, ethnicity, customs, and governance still remain and need a more careful and profound assessment taking the diverse local perspectives on these issues into account. These insights could support and complement knowledge needs on the regional political economy of KSL and its underlying fabric using a series of carefully selected case studies, where key marginalised groups and the institutions that drive or trigger marginalisation are identified and analysed in the context of tourism development. Such information can form the basis for developing a set of community development and tourism activities that focus on building more equitable access to resources across existing social divisions. 
Acknowledgments This study would not have been possible without the participation, support, and interest of all local stakeholders consulted for this study. To them, we extend our appreciation and thanks. The authors would also like to thank Mr. Ram Chandra Sedai, local consultant, for his valuable input into this study. This study was funded by the Deutschen Gesellschaft für Internationale Zusammenarbeit (GIZ) $\mathrm{GmbH}$, with the expert support, facilitation and coordination from ICIMOD. In addition, we wish to gratefully acknowledge the constructive feedback received from three anonymous reviewers. Any remaining errors are our own.

\section{References}

Adger, N. W., Brown, K., \& Hulme, M. (2005). Redefining global environmental change. Global Environmental Change Part A, 15(1), 1-4. doi:10.1016/j.gloenvcha.2004.12.002.

Adhikari, B., Di Falco, S., \& Lovett, J. C. (2004). Household characteristics and forest dependency: Evidence from common property forest management in Nepal. Ecological Economics, 48(2), 245-257. doi:10.1016/j.ecolecon.2003.08.008.

Agrawala, S., Raksakulthai, V., Aalst, M. v., Larsen, P., Smith, J., and Reynolds, J. (2003). Development and climate change in Nepal: Focus on water resources and hydropower. Paris: environment directorate and development co-operation directorate. Working party on global and structural policies and working party on development co-operation and environment. Organisation for economic co-operation and development (OECD).

Asker, S., Boronyak, L., Carrard, N., and Paddon, M. (2010). Effective community based tourism: A best practice manual. Asia pacific economic cooperation (APEC) tourism working group. Gold coast, Australia: sustainable tourism cooperative research centre.

Auer, M. (2007). More aid, better institutions, or both? Sustainability Science, 2(2), 179-187. doi: 10.1007/s11625-007-0029-6.

Bajracharya, S. R., Mool, P. K., and Shrestha, B. R. (2007). Impact of climate change on Himalayan Glaciers and Glacial Lakes: Case studies on GLOF and associated hazards in Nepal and Bhutan. Kathmandu, Nepal: International centre for integrated mountain development (ICIMOD) and United Nations environment programme regional office Asia and the pacific (UNEP/ROAP).

Beebe, J. (1995). Basic concepts and techniques of rapid appraisal. Human Organization, 54(1), 42-51.

Beebe, J. (2003). Rapid assessment process (RAP)—Glossary. http://www.rapidassessment.net/glossary. html. Accessed 06 January 2012.

Beeton, S. (2006). Community development through tourism. Collingwood, Victoria: Land Links.

Bhattachan, K. B. (2002). Traditional local governance in Nepal. Paper presented at the Seminar on strengthening decentralization and good governance in Nepal, 21 April 2002, Kathmandu, Nepal.

Blackstock, K. (2005). A critical look at community based tourism. Community Development Journal, 40(1), 39-49. doi:10.1093/cdj/bsi005.

Brockman, N. C. (2011). Encyclopedia of sacred places-volume 1 (2nd ed.). Santa Barbara, USA: ABCCLIO LLC.

Brown, K. (2011). Sustainable adaptation: An oxymoron? Climate and Development, 3(1), 21-31. doi: 10.3763/cdev.2010.0062.

Brun, G., \& Kuenzle, D. (2008). Introduction: A new role for emotions in epistemology? In G. Brun, U. Doguoglu, \& D. Kuenzle (Eds.), Epistemology and Emotions (Ashgate Epistemology and Mind Series). Hampshire, England: Ashgate.

Brunner, R. D. (2001). Science and the climate change regime. Policy Sciences, 34(1), 1-33. doi:10.1023/A: 1010393101905.

Brunner, R. D., and Lynch, A. H. (2010). Adaptive governance and climate change: The University of Chicago Press.

Butler, R. W. (1999). Sustainable tourism: A state-of-the-art review. Tourism Geographies, 1(1), 7-25.

Chalaune, P. (2010). Water, wealth, and power: A case study from upper mustang of Nepal. Occasional Papers in Sociology and Anthropology, 11, 104-125.

Chaudhary, R. P., Shrestha, K. K., Jha, P. K., and Bhatta, K. P. (2010). Feasibility study of Kailash sacred landscape conservation initiative, Nepal. Kathmandu: International centre for integrated mountain development (ICIMOD).

Desai, B. H., Oli, K. P., Yang, Y., Chettri, N., and Sharma, E. (2011). Implementation of the convention on biological diversity: A retrospective analysis in the Hindu Kush-Himalayan countries. Kathmandu, Nepal: International centre for integrated mountain development (ICIMOD). 
Dubois, J. B. (2005). Addressing climate change through development cooperation: Climate change issues in the field of natural resource management, Livelihoods, and Food Security. Mountain Research and Development, 25(4), 382-383. doi:10.1659/0276-4741(2005)025[0382:acctdc]2.0.co;2.

Eriksen, S., \& Brown, K. (2011). Sustainable adaptation to climate change. Climate and Development, 3(1), 3-6. doi:10.3763/cdev.2010.0064.

Eriksen, S. H., \& O’Brien, K. (2007). Vulnerability, poverty and the need for sustainable adaptation measures. Climate Policy, 7(4), 337-352.

Eriksen, S., Aldunce, P., Bahinipati, C. S., Martins, R. D. A., Molefe, J. I., et al. (2011). When not every response to climate change is a good one: Identifying principles for sustainable adaptation. Climate and Development, 3(1), 7-20. doi:10.3763/cdev.2010.0060.

Gurung, G. M. (1993). Polyandry, adaptability and environment: A case study of Tangin, a Himalayan village in Nepal. Contributions to Nepalese Studies, 20(2), 175-182.

Gurung, C. P., \& De Coursey, M. D. (1994). The Annapurna conservation area project: A pioneering example of sustainable tourism? In E. Cater \& G. Lowman (Eds.), Ecotourism: A sustainable option?. New York: Wiley.

Hobbs, C. (2009). The cost of coping. A collision of crises and the impact of sustained food security deterioration in Nepal. Kathmandu: Nepal food security monitoring system/Nepal Khadya Surakshya Anugaman Pranali (NeKSAP), United Nations World Food Programme.

Hoermann, B. and Kollmair, M. (2009). Labour migration and remittances in the Hindu Kush-Himalayan Region. ICIMOD working paper. Kathmandu, Nepal: International centre for integrated mountain development (ICIMOD).

ICIMOD (2008). About ICIMOD. http://www.icimod.org/?q=abt Accessed 6 January 2012.

ICIMOD (2009a). Inception workshop report kailash sacred landscape conservation initiative. Kathmandu, Nepal: International centre for integrated mountain development (ICIMOD).

ICIMOD (2009b). Landcover map of the Kailash sacred landscape. Kathmandu, Nepal: International centre for integrated mountain development (ICIMOD).

ICIMOD (2010a). Conservation landscapes-HKH conservation portal. http://www.icimod.org/hkh conservationportal/Default.aspx Accessed 09 December 2010.

ICIMOD. (2010b). Terms of reference-Tourism and climate change (September 2010). International centre for integrated mountain development (ICIMOD): Kathmandu.

Jolly, J. (2010). Nepal government to table annual budget. http://www.bbc.co.uk/news/world-south-asia11783245 Accessed 10 December 2010.

Jones, L., \& Boyd, E. (2011). Exploring social barriers to adaptation: Insights from Western Nepal. Global Environmental Change, 21(4), 1262-1274. doi:10.1016/j.gloenvcha.2011.06.002.

Kiss, A. (2004). Is community-based ecotourism a good use of biodiversity conservation funds? Trends in Ecology \& Evolution, 19(5), 232-237. doi:10.1016/j.tree.2004.03.010.

Lasswell, H. D. (1971). A pre-view of policy sciences: Elsevier publishing company.

Levine, N. E. (1987). Caste, state, and ethnic boundaries in Nepal. The Journal of Asian Studies, 46(1), 71-88.

Lynch, A. H., Tryhorn, L., \& Abramson, R. (2008). Working at the boundary: Facilitating interdisciplinarity in climate change adaptation research. Bulletin of the American Meteorological Society, 89(2), 169-179. doi:10.1175/bams-89-2-169.

Majerus, J. (2009). Program design for tourism-related value chains in Humla and Dolpa districts the great Himalaya trail development programme in West Nepal-linking formal and informal enterprises to tourism markets to reduce poverty. Arlington, VA: Action for Enterprise.

Manasfi, N. (2011). Quick but robust: GIZ's search for vulnerability assessments for development cooperation. In: 8th Meeting of the expert working group on measuring vulnerability: Assessing and mapping the dynamics of vulnerability to natural hazards and climate change, 4-7 July, University of Salzburg, Salzburg Austria, 2011: United nations university, institute for environment and human security (UNU-EHS) and centre for geoinformatics (Z_GIS), University of Salzburg Austria.

McEvoy, D., Cavan, G., Handley, J., McMorrow, J., \& Lindley, S. (2008). Changes to climate and visitor behaviour: Implications for vulnerable landscapes in the North West Region of England. Journal of Sustainable Tourism, 16(1), 101-121. doi:10.2167/jost676.0.

McKay, K. H. (2002). Health needs in two ethnic communities of Humla District, Nepal. Contributions to Nepalese Studies, 29(2), 241-273.

Mikkelsen, B. (2005). Methods for development work and research: A new guide for practitioners (2nd ed.). New Dehli, India: SAGE Publications Pvt. Ltd.

MoTCA (2008). Tourism policy 2065 (2008). (in Nepalese) Kathmandu: Ministry of Tourism and Civil Aviation, Nepal Government. 
MoTCA. (2009). Nepal tourism statistics 2009 (annual statistical report). Kathmandu, Nepal: Ministry of Tourism and Civil Aviation.

NEFIN (2005). Bhutia/Bhote. http://www.nefin.org.np/indigenous-nationalities/himalayan-in/20.html, Nepal Federation of Indigenous Nationalities, Accessed 10 January 2012.

Nepal, S. K. (2008). Tourism-induced rural energy consumption in the Annapurna region of Nepal. Tourism Management, 29(1), 89-100.

NIDS. (2005). NGOs working in Humla District: A rapid assessment. Kathmandu, Nepal: Nepal Institute of Development Studies.

Nyaupane, G. P., \& Thapa, B. (2004). Evaluation of ecotourism: A comparative assessment in the Annapurna Conservation Area Project, Nepal. Journal of Ecotourism, 3(1), 20-45. doi:10.1016/ j.annals.2004.01.006.

O'Brien, G., O'Keefe, P., Rose, J., \& Wisner, B. (2006). Climate change and disaster management. Disasters, 30(1), 64-80. doi:10.1111/j.1467-9523.2006.00307.x.

O’Brien, K., Eriksen, S., Nygaard, L. P., \& Schjolden, A. (2007). Why different interpretations of vulnerability matter in climate change discourses. Climate Policy, 7, 73-88.

Onta, N., \& Resurreccion, B. P. (2011). The role of gender and caste in climate adaptation strategies in Nepal. Mountain Research and Development, 31(4), 351-356. doi:10.1659/mrd-journal-d-10-00085.1.

Panter-Brick, C., \& Eggerman, M. (1997). Household responses to food shortages in Western Nepal. Human Organization, 56(2), 190-198.

Patt, A. G., Schroter, D., Klein, R. J. T., and Vega-Leinert, A. C. d. 1. (Eds.). (2009). Assessing vulnerability to global environmental change: Making research useful for adaptation decision making and policy: Earthscan.

Pokharel, S. (2007). An econometric analysis of energy consumption in Nepal. Energy Policy, 35(1), 350-361.

Prabhakar, S., Srinivasan, A., \& Shaw, R. (2009). Climate change and local level disaster risk reduction planning: need, opportunities and challenges. Mitigation and Adaptation Strategies for Global Change, 14(1), 7-33.

Roman, C. E., \& McEvoy, D. (2010). Kailash sacred landscape conservation (KSLCI) strengthening project-Nepal. Tourism and climate change final report. Melbourne, Australia: Climate change adaptation program: Global cities institute, RMIT University.

Roman, C., Chhetri, P., \& McEvoy, D. (2010a). Kailash sacred landscape conservation initiative (KSLCI) strengthening project-Nepal. Climate change and tourism stakeholder workshop report. Melbourne: Climate change adaptation program, Global Cities Research Institute, Royal Melbourne Institute of Technology (RMIT) University.

Roman, C. E., Lynch, A. H., \& Dominey-Howes, D. (2010b). Uncovering the essence of the climate change adaptation problem-A case study of the tourism sector at Alpine Shire, Victoria, Australia. Tourism and Hospitality Planning \& Development, 7(3), 237-252. doi:10.1080/1479053x.2010.503049.

Roman, C. E., Lynch, A. H., \& Dominey-Howes, D. (2011). What is the goal? Framing the climate change adaptation question through a problem-oriented approach. American Meteorological Society's Weather, Climate and Society, 3(1), 16-30. doi:10.1175/2010WCAS1052.1.

Roy, R., Schmidt-Vogt, D., \& Myrholt, O. (2009). "Humla development initiatives" for better livelihoods in the face of isolation and conflict. Mountain Research and Development, 29(3), 211-219. doi:10.1659/ mrd.00026.

Saville, N. M. (2001). Practical strategies for pro-poor tourism: case study of pro-poor tourism and SNV in Humla District, West Nepal. PPT Working Paper No. 3: Overseas development institute (ODI), the international institute for environment and development (IIED), and the centre for responsible tourism at the University of Greenwich (CRT).

Schild, A. (2008). ICIMOD's position on climate change and mountain systems. Mountain Research and Development, 28(3/4), 328-331. doi:10.1659/mrd.mp009.

Schipper, E. L. F., and Burton, I. (Eds.). (2008). The earthscan reader on adaptation to climate change (earthscan reader series).

Schipper, L., \& Pelling, M. (2006). Disaster risk, climate change and international development: scope for, and challenges to, integration. Disasters, 30(1), 19-38. doi:10.1111/j.1467-9523.2006.00304.x.

Secretariat of the convention on biological diversity (2000). Sustaining life on Earth: How the convention on biological diversity promotes nature and human well-being Montreal, Canada: Secretariat of the Convention on Biological Diversity and United Nations Environment Programme (UNEP).

Seeland, K. (2000). What is indigenous knowledge and why does it matter today? In K. Seeland, and F. Schmithuesen (Eds.), Forest use and management in the wider himalayan context-Selected Papers. Zurich: Forest policy and forest economics, Department of Forest Sciences, Swiss Federal Institute of Technology (ETH) Zurich. 
Singh Khadka, N. (2011). Himalaya village caught between culture and nature. http://www.bbc.co.uk/ news/science-environment-14620091 Accessed 10 January 2012.

Smit, B., \& Wandel, J. (2006). Adaptation, adaptive capacity and vulnerability. Global Environmental Change, 16(3), 282-292. doi:10.1016/j.gloenvcha.2006.03.008.

Smit, B., Pilifosova, O., Burton, I., Challenger, B., Huq, S., Klein, R., et al., (2001). Adaptation to climate change in the context of sustainable development and equity. In J. J. McCarthy, Canziani, O., Leary, N. A., Dokken, D. J. and White, K. S (Eds.) (Ed.), In: Climate change 2001: Impacts, adaptation and vulnerability. Contribution of Working Group II to the third assessment report of the intergovernmental panel on climate change (pp. 877-912, Vol. 9). Cambridge: Cambridge University Press.

Smith, J. B., Klein, R. J. T., and Huq, S. (2003). Climate Change, Adaptive Capacity and Development: Imperial College Press.

Thapa, B. (2004). Tourism in Nepal. Journal of Travel and Tourism Marketing, 15(2-3), 117-138. doi: 10.1300/J073v15n02_07.

The World Bank (2010). Research for development: A world bank perspective on future directions for research. Policy Research Working Paper 5437. Washington DC: The World Bank.

Thomalla, F., Downing, T., Spanger-Siegfried, E., Han, G., \& Rockström, J. (2006). Reducing hazard vulnerability: Towards a common approach between disaster risk reduction and climate adaptation. Disasters, 30(1), 39-48.

UNWTO. (2010). Tourism and biodiversity-Achieving common goals towards sustainability. Madrid: United Nations World Tourism Organization.

Upreti, B. R., Sharma, S. R., Pyakuryal, K. N., \& Ghimire, S. (Eds.). (2010). The remake of a state: Postconflict challenges and state building in Nepal. Kathmandu: South Asia regional coordination office of the Swiss national centre of competence in research (NCCR North-South) and Human and Natural Resources Studies Centre (HNRSC), Kathmandu University.

Varughese, G., \& Ostrom, E. (2001). The contested role of heterogeneity in collective action: Some evidence from community forestry in Nepal. World Development, 29(5), 747-766.

Wisner, B., Blaikie, P. M., Cannon, T., and Davies, I. (2004). At Risk: Natural Hazards, People's Vulnerability and Disasters: Routledge, Taylor and Francis Group.

Ziervogel, G., Bharwani, S., \& Downing, T. E. (2006). Adapting to climate variability: Pumpkins, people and policy. Natural Resources Forum, 30(4), 294-305. 